\title{
Review of Adam Smith as theologian, edited by Paul Oslington. London: Routledge, 2011, 146 pp.
}

\author{
JOHAN GRAAFLAND \\ Tilburg University
}

This book is the outcome of a conference in 2009 initiated by Paul Oslington and is a very welcome contribution to a highly interesting subject: how Adam Smith's economic analysis and moral philosophy is embedded in his theological world view. The various papers bundled in this book deepen our understanding of Smith's theories and well known concepts he employs, like the invisible hand and impartial spectator. Anyone interested in the philosophy and economics of Adam Smith will find it very illuminating.

\section{THE RELEVANCE OF THIS BOOK}

Deepening our understanding of Smith's moral philosophy is especially relevant today because, in the aftermath of the economic crisis, many economists and policy makers are again reflecting on the moral basis of the free market. This has revived interest in Adam Smith because he is not only known for being the father of economics, but also for embedding economics in a broader framework of moral philosophy. As a moral philosopher, Adam Smith developed important theories about how commercial society could develop while maintaining and simultaneously developing a moral framework that could assure harmony. Given the dramatic collapse of the market economy in the last few years, putting the welfare and peace of Western society in danger, it is highly relevant to analyse where the current economic system (including the practices of bankers) may have gone off track and how this may be related to a lack of balance in economic and ethical values.

However, in order to understand how and to what extent Smith's moral philosophy might help us understand the shortcomings of the current economic system and identify opportunities for enhancing both its moral basis and economic functioning, one cannot disregard the overall world view of Adam Smith and, consequently, his theology. For this purpose, this book is very timely and helpful. 


\section{STRUCTURE OF THE BOOK}

In order to understand Smith's theology, the book first discusses several distinct influences on Smith, including Augustine, Calvin and Calvinism, natural law, and the British tradition of scientific natural theology. The second part analyses various aspects of Smith's theology such as providence, the invisible hand, Smith's theodicy, and the impartial spectator. Most contributions are interesting and well informed, and go beyond the better known citations to discuss lesser noted passages from Smith's works that nicely clarify his theological position.

The involvement of so many authors in so short a volume has advantages and disadvantages. On the one hand, one gets a rather complete picture and a sense of the degree of academic consensus in judging Smith's theological position. On the other hand, since the authors have such limited space, the analysis is sometimes rather sketchy (though the reader is often referred to lengthier treatments of the issues elsewhere).

It would have been interesting if the book would also have dealt more systematically with the affinities and differences between Smith's Christian theology and the different theological positions in today's churches (Calvinist, Lutheran, Catholic, Evangelical, Ecumenical, and so forth). This would have enabled the general reader to map Smith in relation to the various contemporary Christian approaches to economic order and policy, and also helped readers from different ecclesiastic traditions to understand the extent to which Smith is still applicable and informative for their theological position.

It might also have been better to involve more theologians in the project. Although the present authors provide good and informative analyses, only a minority of them seem to be professionally trained in theology, as far as I can see from the list of contributors. This may diminish the theological depth of the analysis.

\section{DISCUSSION OF INDIVIDUAL CONTRIBUTIONS}

The book starts off with a good introduction by Paul Oslington. He argues that the presumption of a theological dimension to Smith's work is justified by the many (403) references to God in his published works, of which 30\% are explicitly Christian and 39\% implicitly Christian. Oslington describes four types of influences on the theological content of Smith's work: Stoicism, Scottish Calvinism, British Scientific natural theology, and natural law, and argues that the second and third are 
probably the most important ones. However, Oslington neglects a seemingly central issue. How significant was Smith's theology to his moral and economic analysis? For example, what service did Smith's theological doctrines perform in his theories that would have caused him problems if he had left them out entirely? Benjamin Friedman's short contribution is somewhat disappointing. Firstly, in contrast to what he states, the idea that self-interest might have broader beneficial consequences was already well known before the 18th century. For example, in 1656 Joseph Lee argued in $A$ vindication of a regulated enclosure that the public interest would be served if everybody were able to act in accordance to his or her self interest. Secondly, Friedman links the rise in economic thinking to the decline of orthodox Calvinism. That seems to conflict with the contribution of Blosser showing the continuity between orthodox Calvinism and Smith. Thirdly, one can question to what extent the transition from pessimistic (Calvinist) to more optimistic theological doctrines has really contributed to a realistic view on the economy. The credit crisis indicates that a bit more pessimism about human nature is not unrealistic, and so Calvin's theology (and economic insights) may still be very fruitful for identifying the shortcomings of modern economics (Graafland 2010). Fourthly, it would have been interesting if Friedman had worked out in more detail his thesis that the religious resonances in Smith's writings have significant implications for a variety of ongoing debates about economics and economic policy today. Because it does not seem that obvious.

John Haldane gives a nice sketch of the fragility of Smith's theology. On the one hand, there are indications that he remained a believing Christian throughout his life and adopted natural theology. On the other hand, he was moving away from a theologically rooted form of ethics towards a naturalist foundation in a theory of human nature, although he retained some confidence in certain natural-theology claims. Haldane provides evidence for this development both from Smith's life and his Theory of moral sentiments (TMS henceforth), which suggest that Smith ended up close to ethical naturalism.

Eric Gregory describes an interesting parallel between Augustine and Smith (notwithstanding their important differences, on which see also the contributions of Harrison and Pabst). Both are markedly disinclined to pursue the modern quest for a universal ethic based on reason because as virtue ethicists they both assume that relationship-based 
sentimental sources, like love and sympathy, are fundamental to moral order. This contrasts with modern liberal political philosophers, such as Hannah Arendt or John Rawls, who criticize personal morality as a basis for politics and want to make justice independent of sentiments. Of course, Smith and Augustine differ in their approach to virtue ethics: Smith grounds moral authority in a relational self that is responsive to the judgements of others, whereas Augustine perceives virtue as a God given characteristic. But Gregory suggests they can both offer an important alternative to the 'cold' liberalism that supposes that society only needs just institutions, not love or sympathy.

Joe Blosser develops the thesis that Smith articulates a multidimensional view of human freedom that is broader than the dominant notion of freedom as the absence of coercion so often stressed by economists. In his view, Smith also included a notion of freedom as the power to pursue the ends for which God created humans. According to Bossler, this becomes clear when one researches the link between Smith and Calvinism. Both defend the providence of God that steers human actions towards the good and lets them participate in God's plan. Both Smith and Calvin hold that humans can be freed from moral laws, that conscience, not the moral law, has the final word. Bossler does not deny the differences between Calvin and Smith. For example, that in Calvin's theology freedom from the moral law is justified by faith; whereas in Smith's theology freedom is founded in the conscience of the truly virtuous. More significantly, in Calvin's view the core value that human freedom should aim at is the glory of God and enjoyment of Him, whereas Smith's final goal is human happiness only. As Blosser puts it, "Smith writes of a God made for humans, not of humans made for God" (p. 56). Blosser does not explain, however, whether this crucial difference drives a wedge between the concepts of freedom held by Calvin and Smith.

In chapter 5, Oslington works out the theological meaning of the well known Smithian metaphor of the 'invisible hand'. He correctly shows that Smith's use of this concept has roots in natural theological accounts of divine action and providence. Oslington illustrates his point by several citations from TMS and The wealth of nations (WN hereafter) that are very clearly connected to the British natural theology tradition and suggest that, in this, Smith was inspired by Newton. 
Oslington also introduces a distinction between general and special providence, meaning that God's care is expressed in the regularity of the universe and in God's irregular acts, respectively. Oslington argues that the metaphor of the invisible hand as used by Smith refers to special providence, but his argument is very sketchy. If the distinction is relevant at all, I would rather argue for the opposite, as Smith's invisible hand operates on a regular rather than an incidental basis and is structurally related to the nature of man and various constants in human interactions. Oslington is right that the invisible hand cannot be equated to the market or price mechanism, but his argument that the operation of the invisible hand only applies to certain cases is not convincing. As far as I know, Smith nowhere limits the operation of the invisible hand, for example to a specific type of people or the fulfilment of specific conditions (as is often the case for special providence in theology). On the contrary, as is evident from Harrison's discussion of Smith's use of the invisible hand and divine watchmaker metaphors, the invisible hand "overrules all events to ends suitable to the highest wisdom and goodness" (p. 86).

In his chapter on natural theology Peter Harrison describes how at the end of the 17th century some aspects of the natural and social world, which had always been perceived as evidence of original sin, came instead to be regarded as evidence of God's providential design. Harrison shows how the principles that informed Smith's approach were commonplace in early modern natural theology (for example in the writing of Matthew Barker) and it is likely that Smith used them in a similar way. Thus, whereas Augustine interpreted self-love as the characteristic vice of citizens of the earthly city, Smith regarded it a natural characteristic and evidence of God's providential design. To me, this analysis is very convincing and I think Harrison is right when he concludes that Smith's thinking was strongly influenced by considerations of natural theology.

In another well written chapter James Otteson elaborates on Smith's use of the term 'impartial spectator'. Otteson compares this to Milton Friedman's interpretation of economic assumptions as idealizations whose strict falsehood is irrelevant (Friedman 1953). Likewise, we are able to understand human moral behaviour if we assume that people have a conception of morality such that they think that an action is right if it would be approved by an impartial spectator. The impartial spectator stands for two ideal conditions: being fully informed and 
disinterested (p. 94). Addressing the origins of the impartial spectator, Otteson refers to Parts I-III of TMS and sketches its gradual development from the narrow perspective of a child to the generalized perspective that the well-socialised individual develops through his experiences of what other actual spectators have approved or disapproved of in various circumstances. The connection with God is that the impartial spectator thus developed, although fallible, generates standards of social judgment that are as close to an idealized perfection as could be hoped for from limited and fallen creatures. And this is itself a reason to believe it is an aspect of God's providence.

Brendan Long defends the thesis that Smith's theism is genuinely Christian, as evidenced particularly by his emphasis on The Golden Rule. ${ }^{1}$ People do not arrive at such ethics because they are naturally altruistic, but rather through natural and social mechanisms that constrain and direct self-love. Excessive self-love is overcome by the countervailing forces of sympathy and the judgement of spectators, and by considering the negative unintended consequences it may have (prudence). The realisation of a decent social order is therefore not the result of individuals' virtues (which Smith considered to be rare), but rather of this kind of reciprocal mechanism. The ultimate cause behind this is the Divine providential will.

After this excellent exposition, Long notes the contrasts between Smith and traditional Christianity. In particular, because of his natural theology, Smith tends to elide the problem of evil. All evil is only partial and is turned to the good by the providential care of God. He does not consider the possibility that evil will not be corrected. Here Long makes clear that Smith can be regarded as an optimist, because there is no logical reason why positive unintended consequences would necessarily overcome either the negative intentions behind human behaviour or its negative unintended consequences. It could be that self-love drives pervasive evil in society. This shows that Smith is clearly a child of the positive mood of the early modern period; there is no place for the darkest depths of human nature. I strongly agree and I think this should also make us alert that we may need more than Adam Smith has to offer to revive proper attention to morality in economics.

\footnotetext{
${ }^{1}$ See, for example, the passage: "As to love our neighbour as we love ourselves is the great law of Christianity, so it is the great precept of nature to love ourselves only as we love our neighbour, or what comes to the same thing, as our neighbour is capable of loving us" (TMS, I.I.44).
} 
Adrian Pabst's contribution also considers Smith's natural theology and its differences with Augustine's. A new element in his interesting but difficult chapter is his analysis of Smith's position regarding the role of civil organisations in society. Pabst shows that Smith opposed the idea that intermediary organisations are indispensable for public well being. Pabst refers to the well know passage wherein Smith criticizes meetings of people of the same trade for leading to price-fixing agreements (WN, I.10.82). Pabst does not offer, however, an analysis of the actual societal role of those intermediary organisations (like university colleges and guilds) in Smith's time, which might have supported Smith's critical attitude. Nevertheless, his analysis shows the limitations of applying Smith to the modern economy, because nowadays the positive role of societal associations is well recognized, and even business organisations are considered important in organising self regulation.

Ross Emmett also gives a good description of Smith's concept of the impartial spectator as a natural basis for moral judgement (see also Otteson's chapter). He provides an interesting and relevant description of how the impartial spectator differs from what he calls 'the man of system'. Unfortunately, he does not discuss its relationship with Smith's theology.

One may wonder, for example, whether Smith's naturalistic account of morality risks degenerating into an entirely relativistic account. Maybe that is why Smith links the impartial spectator explicitly to God's providence, thereby providing a reason to believe that the morality thus developed is a good morality. But, as the Bible shows, God may also allow people that reject him to be led astray by their own wisdom (Rom. 1: 28-32). In this way God punishes them for not acknowledging Him as God. That means that God's providence does not necessarily lead to good morality.

The book closes with a very nice chapter by Paul Williams. First, he presents an informative and convincing analysis of the difference in anthropology between Adam Smith and both modern economics and utilitarianism. But then he notes, rightly, that Smith is not entirely consistent. Indeed, as I describe elsewhere (Graafland 2007), Smith also defends divergences from virtue ethics by applying utilitarian considerations, suggesting that, in the end, he is a utilitarian rather than a virtue ethicist. Williams derives an important conclusion from the well known passage on the invisible hand in TMS, namely that Smith himself 
had not fully reckoned on the possibility that a society built on predominantly utilitarian motives could systematically undermine virtue. Finally Williams makes a plea for a consistent theological reorientation of economics that adopts a teleological notion of the good, of which Smith's theology falls short.

\section{CONCLUDING REMARK}

Taken together this book provides us with a very interesting picture of Smith's theology and its relationship with his moral philosophy and economics. At the same time, this picture shows us that Adam Smith's theological worldview will not provide us with all the answers we need to meet today's economic challenges. On the contrary, it leaves ample room for further critical reflection on the current economic order from a Christian or theological perspective.

\section{REFERENCES}

Graafland, Johan J. 2007. Economics, ethics, and the market: introduction and applications. London: Routledge.

Graafland, Johan J. 2010. Calvin's restrictions on interest: guidelines for the credit crisis. Journal of Business Ethics, 96 (1), 233-248.

Lee, Joseph. 1656. A vindication of a regulated enclosure. London: E. C. Thomas Williams.

Friedman, Milton. 1953. The methodology of positive economics. In Essays in positive economics, Milton Friedman. Chicago: University of Chicago Press, 3-43.

Johan Graafland is professor in economics, business, and ethics at Tilburg University, The Netherlands. His research focuses on the fields of macroeconomic ethics, business ethics/corporate social responsibility, and the Christian view of the economy. His most recent book is The market, happiness, and solidarity: a Christian perspective (Routledge, 2010).

Contact e-mail: $<$ j.j.graafland-at-uvt.nl $>$ 